\title{
$ノ-$ ト
}

\section{白金対極の電解溶出を利用したアミノ化カーボン電極上への 白金ナノ粒子の電析とその表面特性解析}

\author{
島村 千尋 ${ }^{\mathrm{a}}$, 陣内 意康 ${ }^{\mathrm{b}}$, サトリオクントラックソノ ${ }^{\mathrm{a}}$, 佐藤 進 ${ }^{\mathrm{b}}$, 松浦 宏昭 ${ }^{\mathrm{a},{ }^{*}}$ \\ a 埼玉工業大学大学院工学研究科 生命環境化学専攻 ( ₹ 369-0293 埼玉県深谷市普済寺 1690) \\ ${ }^{b}$ 埼玉工業大学大学院工学研究科 情報システム専攻 ( ⿳ 369-0293 埼玉県深谷市普済寺 1690)
}

\section{Electrodeposition and Characterization of Platinum Nanoparticles onto Aminated Carbon Electrodes Using Electrochemical Dissolution of Platinum Counter Electrode}

\section{Chihiro SHIMAMURA ${ }^{\text {a }}$, Motoyasu JINNAI ${ }^{\text {, }}$, Satrio KUNTOLAKSONO ${ }^{\text {a }}$, Susumu SATO ${ }^{\text {b }}$ and Hiroaki MATSUURA ${ }^{\text {a, }}$}

\begin{abstract}
${ }^{a}$ Department of Life Science \& Green Chemistry, Graduate School of Engineering, Saitama Institute of Technology (1690 Fusaiji, Fukaya, Saitama 369-0293)

${ }^{\mathrm{b}}$ Department of Information Systems, Graduate School of Engineering, Saitama Institute of Technology (1690 Fusaiji, Fukaya, Saitama 369-0293)
\end{abstract}

\begin{abstract}
Using the electrochemical dissolution phenomenon of platinum counter electrode, we investigated the surface functionalization and characterization of platinum nanoparticles that had been electrodeposited onto aminated carbon electrodes. The electrodeposited platinum functions with nitrogen-atom-containing functional groups introduced by electrolysis in ammonium carbamate solution. The groups can include aromatic amine groups such as aniline. Together, they function as active sites of specific electrocatalytic current, as found from SEM and XPS observations and electrochemical properties.
\end{abstract}

Keywords : Electrochemical dissolution, Platinum Nanoparticles, Aminated Carbon Electrodes, Platinum Deposition

\section{1. 緒言}

電気めっき技術は固体表面の改質技術として活用され，材 料全般の腐食防食などの機能を付与する技術として古くから 多用されてきた ${ }^{1,2)}$ 。他方では, 電気めっき技術を金属ナノ 粒子の形成に応用する研究が報告されている。例えば西村ら は, 炭素担体上に触媒活性の高い白金ナノ粒子が直接形成さ せる電解処理法を提案している ${ }^{3)}$ 。この手法は, 陰極に炭素 担体を用い，その対極 (白金)を陽極として電解することで, 陽極から白金が溶出し, 陰極の炭素担体表面に白金が電析す る。加えて, 印加電位や電解時間といった反応条件を変える ことで，陽極からの白金の溶出や電析の速度を制御できる。 このため, 形成される白金ナノ粒子の形状を制御することが 容易である特長をもつ。

最近我々は, 導電性カーボン電極の表面構造を電気化学的 に改質する新たな手法の開発を進めている。特に, 内山らが 報告した手法 ${ }^{4)}$ を活用し, 窒素原子から構成される官能基群 を表面に導入した新規なカーボン電極材料を開発している。 これら作製した電極は, その表面に導入した含窒素官能基群 が電子伝達メディエーターとして機能し, それに由来する触 媒電流が観察できる特長から電気化学センサへの応用展開が

\footnotetext{
*E-mail : matsuura@sit.ac.jp
}

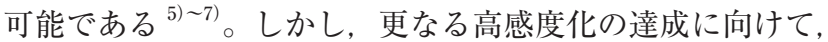
より大きな触媒電流応答を得るためには, 触媒活性の高い白 金ナノ粒子を活用すること, 加えてメディエーターとして機 能する含窒素官能基群と白金ナノ粒子との密着の効果により, 直接炭素表面に電析させた白金ナノ粒子と比べて, 密着性の 向上が期待できる。そこで本研究では, 電池や電気化学分析 用に幅広く使われているカーボン䋊維(カーボンフェルト; $\mathrm{CF})$ やグラッシーカーボン (GC) 電極にアミノ基等の含窒素

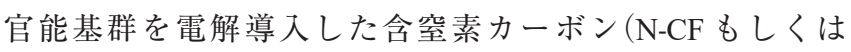
N-GC) 電極を作製し，その表面に白金対極の電解溶出を供給 手段とする白金ナノ粒子の形成について検討した。特に, 超 希薄な白金イオンが含まれる電解液中からの白金電析による 表面構造, 基材表面の含窒素官能基群との相互作用による白 金ナノ粒子の化学的特質, さらにその電気化学特性について 検討した結果を報告する。

\section{2. 実験方法}

本実験で用いた試薬は, すべて試薬特級品である。カーボ ンフェルト $(\mathrm{CF}$; 日本カーボン製 $)$ を $10 \mathrm{~mm}$ 角, 厚さ $5 \mathrm{~mm}$ の大きさに裁断し, 水とエタノールの混合溶液 (体積比で 1 : 1)に浸して 1 時間超音波処理を施して前処理した。一方, 直 径 $6 \mathrm{~mm}$ のグラッシーカーボン ( $\mathrm{GC}$; 日厚計測製) 電極の表 面を $1 \mu \mathrm{m}$ のダイヤモンド研磨剤, 次いで $0.05 \mu \mathrm{m}$ のアルミ 
ナ研磨剤で研磨し，その後 2 分間超音波処理を施して表面を 清浄化した。次に, 調製した $0.1 \mathrm{~mol} / \mathrm{dm}^{3}$ カルバミン酸アン モニウム溶液中に上述処理を施した CFもしくは GC 電極を 浸して, $1000 \pm 100 \mathrm{rpm}$ で溶液を摚拌させながら, + $1.1 \mathrm{~V}$ (vs $\mathrm{Ag} / \mathrm{AgCl})$ の電位を 1 時間印加して電解酸化を行い, それら 表面に含窒素官能基群を電解導入した。その後直ちに, 上述 の含窒素官能基群を導入した $\mathrm{CF}(\mathrm{N}-\mathrm{CF})$ もしくは GC (N-GC) 電極を $1 \mathrm{~mol} / \mathrm{dm}^{3}$ の硫酸に浸し, $-1.0 \mathrm{~V}(\mathrm{vs} \mathrm{Ag} / \mathrm{AgCl})$ の電位 を 20 時間連続で印加し電解還元した。この電解還元の過程 では，使用した白金対極の電解溶出とその電析により，上述 の N-CF や N-GC 電極の表面に白金ナノ粒子を析出させるこ とができ，それぞれ白金ナノ粒子電析含窒素 $\mathrm{CF}(\mathrm{Pt}-\mathrm{NCF})$ お よび白金ナノ粒子電析含窒素 GC (Pt-NGC) とした。作製し たPt-NCF については，その表面を SEM およびXPS にて解 析した。なお, XPS 解析において, 各元素のエネルギーピー クは $\mathrm{C} 1 \mathrm{~s}$ ピークの位置を $284.6 \mathrm{eV}$ として補正を行った。また, 定量的な電極応答特性を評価するために, Pt-NGC 電極の酸 素還元特性を対流ボルタンメトリーにて評価した。

\section{3. 結果と考察}

\section{1 N-CF 表面への白金粒子の電析過程の追跡}

$\mathrm{N}-\mathrm{CF}$ 表面への白金ナノ粒子の電析過程における還元電流 応答の変化を観察したところ, $-1.0 \mathrm{~V}(\mathrm{vs} . \mathrm{Ag} / \mathrm{AgCl})$ の電位 を印加した最初の 1 時間程度は, 平均約 $-0.3 \mathrm{~A} / \mathrm{h}$ の速度で 還元電流は増大し, その後電流変化は徐々に緩やかとなって 20 時間程でほぼ一定の值を示した。この還元電流の増大は, $\mathrm{N}-\mathrm{CF}$ 表面の状態変化に加えて, N-CF 電極からの気泡の発生 を鑑みて水素発生に伴う電流であると考えられる。即ち, $\mathrm{N}-\mathrm{CF}$ 等のプロトン還元の過電圧が大きい材料を電極とした 場合，その表面への白金の電析によりプロトン還元の触媒電 流は急速に大きくなる ${ }^{8)}$ 。このため, この還元電流の増大は, 白金の電析に対応していると判断でき, N-CF の電解還元の 時間経過に伴って電極表面に白金粒子が電析していることを 示唆する結果となった。

\section{2 Pt-NCF 表面に電析した白金ナノ粒子の観察とその 表面特性解析}

作製したPt-NCF の表面を SEMにて観察した結果を図 1 に示す。直径十数 $\mu \mathrm{m}$ のカーボン繊維表面に, 白色で示され る粒子の存在が確認できた。この粒子を EDXで分析した結

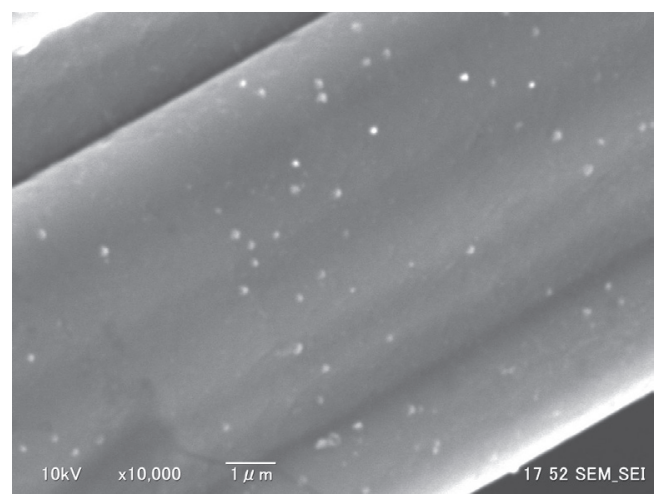

Fig. 1 SEM image of Pt-NCF electrode surface
果，白金と判明した。またその粒子のサイズは $100 \mathrm{~nm}$ 以下 であった。これら結果から, N-CF 電極の電解還元過程にお いて, 対極白金から電解液中に溶出した白金イオンが N-CF 電極の表面で電析し，白金ナノ粒子が形成されることを確認 した。次に, Pt-NCF 表面および CF に直接白金粒子を電析さ せて作製した Pt-CF 表面の XPS スペクトル (白金 $(\mathrm{Pt} 4 \mathrm{f}))$ を 測定し，白金の結合エネルギーについて評価した。なお $2 つ$ の測定試料は, 純水中で 10 分間超音波処理を施し, その後 乾燥させたものをそれぞれ用いた。図 2 に示すように, PtNCF と Pt-CF いずれの表面においても，2つの白金に由来す るスペクトル (白金の $4 \mathrm{f}_{7 / 2}$ と $4 \mathrm{f}_{5 / 2}$ の 2 本のピーク ${ }^{9)}$ )が観察さ れた。一方で大変興味深いことに, Pt-NCF の XPS スペクト ル (a) は, Pt-CF のそれ (b) と比較して, 2つのスペクトルピー クがいずれも $1 \mathrm{eV}$ ほど高結合エネルギー側にシフトしてい た。これは，測定した白金の電荷や配位状態が異なることを 意味する ${ }^{10)}$ 。即ち, Pt-NCF 表面に電析した白金ナノ粒子は, Pt-NCF 表面の含窒素官能基群の窒素原子 ${ }^{11)}$ との相互作用, 特に錯体形成反応に相当するような配位結合による相互作用 の影響を受け，白金の電子状態の変化が反映されていると考 えられる ${ }^{12)}$ 。これら結果から, Pt-NCF 表面の白金ナノ粒子は, Pt-CF のそれと比較して, 化学的特質が大きく異なることが 明らかとなり, 加えて白金粒子の密着性や電極としての反応 特性に違いが生じることを期待する結果を得た。

\section{3 対流ボルタンメトリーによる Pt-NGC 電極の電気 化学特性の評価}

Pt-NGC 電極の酸素還元特性について, $1.0 \mathrm{~mol} / \mathrm{dm}^{3}$ の硫酸 中に $50 \mathrm{~mL} / \mathrm{min}$. の流量で酸素ガスをバブリングしながら対 流ボルタモグラムを測定した結果(図 $3(\mathrm{a})$ ), 酸素の電解還 元に伴う還元応答が観察された。この電極特性は, 白金デイ スク電極を用いた場合と同様な傾向であることが確認できた。 一方, $+0.05 \mathrm{~V}$ (vs. $\mathrm{Ag} / \mathrm{AgCl}$ )における酸素還元の限界電流值 に対して電極回転数 $(1000 \sim 5000 \mathrm{rpm})$ の平方根をプロット (Levich プロット $\left.{ }^{13)}\right)$ したところ，原点を通る直線を示した。 この結果から, Pt-NGC 電極の酸素還元反応は, 電気化学的 に可逆な系であると判断できる。次に，電析した白金ナノ粒 子の密着性を確認するために，超音波処理をそれぞれ 1 ～ 3

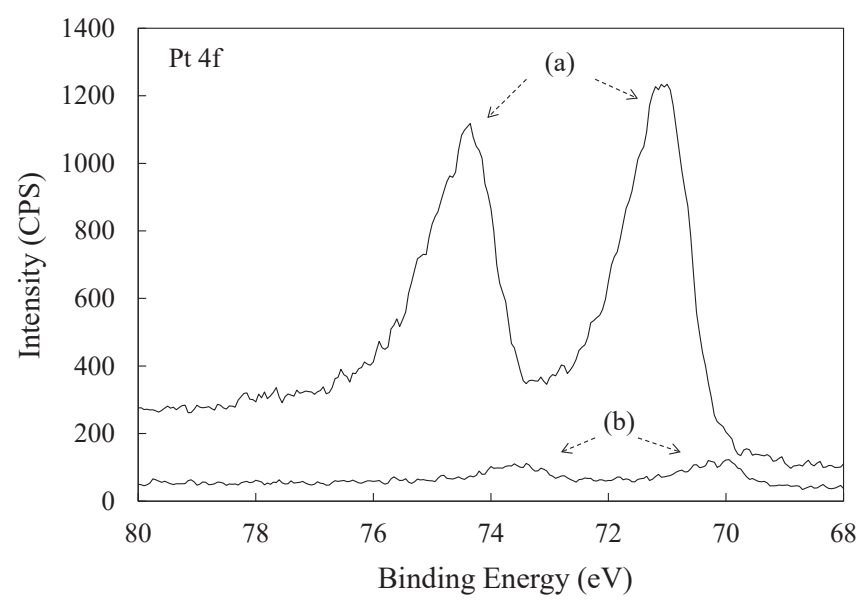

Fig. 2 XPS spectra of Pt $4 \mathrm{f}$ on various electrodes after ultrasonic treatment for 10 minutes. (a) Pt-NCF electrode, (b) Pt-CF electrode 


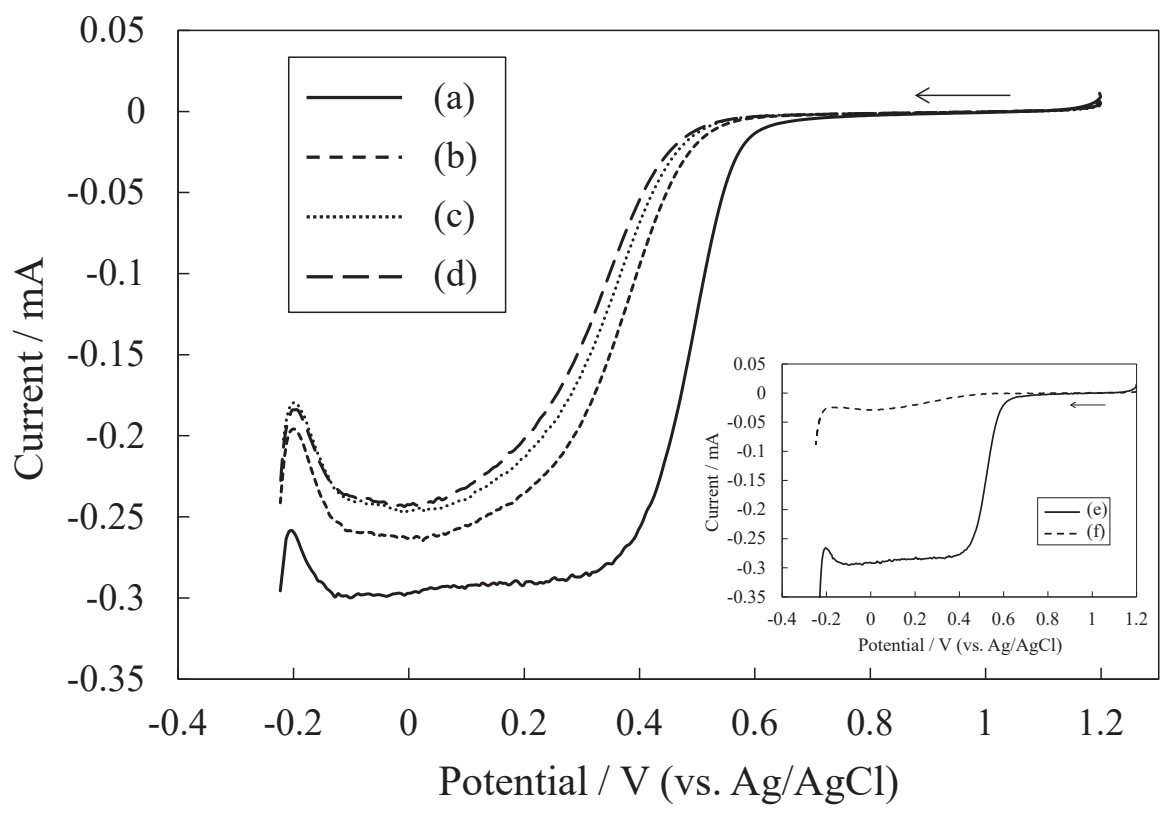

Fig. 3 Hydrodynamic voltammograms of Pt-NCF electrode (a), after ultrasonic treatment for 1 minute (b) , 2 minutes (c) and 3 minutes (d). Inset: hydrodynamic voltammograms of Pt-CF electrode (e), after ultrasonic treatment for (f) 1 minute. Supporting electrolyte: $1.0 \mathrm{~mol} / \mathrm{dm}^{3}$ sulfuric acid; Rotation speed of electrode: $1000 \mathrm{rpm}$; Sweep rate: $50 \mathrm{mV} / \mathrm{s}$.

分施した Pt-NGC 電極の電極応答特性を調べたところ, 酸素 還元の限界電流值は最大で $20 \%$ 程度の低下に止まっていた (図 $3(\mathrm{~b}) \sim(\mathrm{d}))$ 。これは, 超音波処理により, 電析した白金 ナノ粒子の一部が脱落したことを意味しているが, 酸素還元 特性はほぼ維持されていることを示している。一方，超音波 処理を 1 分施した GC に直接白金粒子を電析させて作製した Pt-GC 電極で同様の実験を行ったところ, 酸素還元の限界電 流は $90 \%$ 以上の大幅な低下が確認された(図 3 (e) と (f))。 即ち, Pt-NGC 電極は, 電析した白金ナノ粒子と含窒素官能 基群との相互作用の影響により，その表面に白金ナノ粒子が 強固に密着していることを示唆している。以上のこれら結果 から， Pt-NGC 電極が高い安定性を有する電極触媒としての 特長を示すことが明確となった。

\section{4. 結言}

アミノ基に代表される含窒素官能基群を電解導入したカー ボン材料表面に, 対極白金の電解溶出を利用した白金ナノ粒 子の形成とその表面構造特性を解明した。特に，カーボン表 面の含窒素官能基群と白金ナノ粒子との相互作用により, 白 金ナノ粒子の表面密着がより安定化され，その特質は電気化 学測定の結果からも明らかとなった。従来の電気化学センサ 用の電極触媒は, ナフィオン等の多くのバインダーを使用し て高温条件下で処理する必要があり，作製工程が煩雑である。 一方, 電析という電気めっき技術を適用することで, 電極材 料作製の適用範囲を大きく拡大することが可能であり, 本研 究で提案した含窒素カーボンへの電気めっきの新たな活用法
として大変興味深い知見である。

(Received August 6, 2020 ; Accepted September 14, 2020)

\section{文献}

1 ) S. Koura ; J. Surf. Finish. Soc. Jpn., 70, 576 (2019).

2 ) C. R. K. Rao, D. C. Trivedi ; Coordination Chem. Rev., 249, 613 (2005)

3 ) T. Nishimura, T. Nakade, T. Morikawa, H. Inoue ; Electrochimica Acta, 129, 152 (2014).

$4)$ S. Uchiyama, H. Watanabe, H. Yamazaki, A. Kanazawa, H. Hamana, Y. Okabe ; J. Electrochem. Soc., 154, F31 (2007).

5 ) M. Jinnai, C. Shimamura, S. Kuntolaksono, Y. Tokoyo, S. Sato, H. Matsuura ; Electrochemistry, in press (Published online: June 23, 2020).

6 ) S. Kuntolaksono, H. Matsuura ; Sensors \& Materials, 31, (4), 1215 (2019).

7 ) Y. Yamawaki, K. Asaka, H. Matsuura, S. Uchiyama ; Bunseki Kagaku, 63, 411 (2014).

8 ) M. Kikuchi, T. Yasukawa, F. Mizutani ; J. Surf. Finish. Soc. Jpn., 64, 190 (2013).

9 ) J. F. Moulder, W. F. Stickle, P. E. Sobol, K. D. Bomben ; Handbook of X-ray Photoelectron Spectroscopy, J. Chastain ed., Perkin-Elmer Corporation, Minnesota (1992).

10) M. Nagoshi ; Journal of Surface Analysis, 7, 78 (2000).

11) A. Kanazawa, T. Okajima, S. Uchiyama, A. Kawauchi, T. Osaka ; Langmuir, 30, 5297 (2014).

12) Y. Yoshida ; Journal of the Imaging Society of Japan, 50, 463 (2011).

13）電気化学会編；電気化学測定法マニュアル基礎編, p.131 (丸善, 2002). 